DOI: 10.20472/BMC.2017.006.017

TEMUR SHENGELIA

Tbilisi State University, Georgia

\title{
DETERMINATION OF CORRELATIVE RELATIONS BETWEEN SOCIAL CAPITAL, TRUST AND MOTIVATION IN THE INTERNATIONAL COMPANY
}

\begin{abstract}
:
Conception of the Social Capital is used by many scientists. It established its wide place in economic, social, politological and other sciences. Along with natural and human capital the social capital essentially influences the growth of efficiency of the transnational companies and promotes their development. The social capital is not the property of individual persons, it is established in the social networks and differs from other forms of capital by the fact that it is reflected not in objects and sujects, but in the human relations that form a social network. In general, conception of the social capital is inhomogenous and contracdictory. Despite this, it still establishes a worthy place in economic and social science. Conception of the social capital is based on the phenomenon of confidence. On the basis of ethical and philosophical analysis of the category of confidence it can be convincingly said that without this category development of the society is impossible only by the economic mechanisms. The present study, on the basis of theoretical-methodological, regressive analysis of categories of the social capital and confidence, establishes those empiric relations, which exist between these two categories. Use of the auggested methodology in improvement of the management activity of the modern corporations is important, because it promotes their development and growth.
\end{abstract}

\section{Keywords:}

social capital, motivation, relations, methodology of measuring, corporations, efficiency.

JEL Classification: M16 


\section{Introduction}

The scientists have determined that a level of the unterpersonal and organizational confidence positively influences motivation of the company employees. Volume of confidence accumulated by the social system is its basic capital. Confidence, as a component part of the corporative culture, in the modern competitive economy is a far greater problem than simply management of the personal. In the companies, in which the degree of confidence is low, efficiency falls and competitiveness weakens. We should search for the reasons of this in low motivation of the professional activity. It is also clear that the confidence does not give a guarantee of high professional motivation. But it is an obligatory term of its formation. The studies prove that the confidence is considered to be a basis for not only interpersonal relations, but also for efficiency of the companies' activities. We can suppose that the confidence is one of the most important factors, which influences professional motivation of the personnel.

The studies, dedicated to the problem of relation between the social capital and the confidence, incompletely reflect the connection between these two categories and their influence on increase of the motivation among the employees of the companies. Our study is oriented on promotion to a deeper understanding of this problem.

\section{Literature Review}

Scientific fundamentals of research on conception of the social capital and the confidence are established in the works of E. Durkheim and M. Weber. The scientists consider that the confidence is not an individual feature, which characterizes only a person, but spreads completely on the social group or the society (Demkin, 2004). For the first time the term "social capital" was used by renowned scientist L. Hanifan in the discussion "Important substances in everyday life of people". Group solidarity and social relations are considered by L. Hanifan to be such "substances" (Lanzmann, 2007). We come across a systematic analysis of the social capital in the works of French sociologist Bourdieu. He explains the social capital, as "unity of potential resources, which are related by institutionalized strong networks of mutual acquiantance and acknowledgement" (Bourdieu, 2002). It is seen from this explanation of P. Bourdieu that the social capital represents the resources existing in the social netwoks. Concept "the social capital" is quite widely explained by J. Coleman. In his opinion, the social capital is the potential of mutual confidence and mutual support, which is deliberately established in interpersonal relations (Coleman, 2001). In the studies, conducted by $\mathrm{R}$. Patnem, in the analysis of the social capital, the accent is focused on the nature of its economic, public wellbeing. The present approach, which was further developed in the works of F. Fukuyama and other schientists, much determined the present condition of scientific discussions in this branch. 
Main idea of F. Fukuyama is that excess of confidence in the society generates the social capital, which differs from other forms of the human capital by that it is formed and transferred through such cultural mechanisms, as is religion, tradition or historical customs and habits (Fukuyama, 2006).

On the basis of comparison of capital with the material forms and their analysis a conclusion can be made that the category "social capital" is characterized by the following features: 1 . The social capital, the same as the material forms of the capiyal, is a resource, which is fiormed in the sphere of social relations and has an ability of conversion; 2 . The social capital differs from the material forms of the capital, as it is located in the structure of relations; 3 . The social capital is not an object of property, it is formed in the social networks ( $p$ 5, Shengelia, 2012).

Conception of the social capital is based on the concept of confidence (Lanzmann, 2007). It should be surely said that without confidence the society development is impossible only by the economic mechanisms. On the basis of ethical-philosophical analysis we can outline four most important sides of the present phenomenon: confidence is discussed as the system of moral relations between people; an act of confidence is characterized as a volunary manifestation of the subject; confidence is realized by way of transmitting the intimate ideas and sentiments.

\section{Research of Methodology}

51 persons took part in the research, which were engaged in the international company "Wendy's". In the process of research were selected people from 30 to 55 years of age, which had high education; in the group were 25 women and 25 men. Thus a gender balance was preserved.

In the process of research was used the methodology of assessment of the social capital of organization, established by R. Shaw (Shaw, 2014), which involved several stages.

1. At the first stage the questions involved 10 polar evidences, connected with the factor of confidence in the organization. The answers were evaluated from 1 to 5 scores.

2. Second stage imvolved the questions, concerning motivation of human labor activity. The methodology for evaluation of the motives for work was elaborated in the socio-psychological laboratory of the Tbilisi State University Center of Fundamental Research (Shengelia, 2012). By this methodology a respondent was demanded to define priorities, to select meaning of each motive. In the process of assessment were used scores from 1 to 10 . An important priority was assessed by 1 score and unimportant - by 10 . 
3. Further questions were oriented to revealing of stimuli, which motivate best performance of professional activity by the employees. The questionary suggests 5 stimuli, such as: high salary, possibility to receive a premium, participation in the profit of the organization, the perspective to become one of the owners of the company, possibility to settle important tasks. The answers vary from 1 score "do not stimulate" to 5 scores - "stimulate very much".

III. Next group of questions is connected with the individual data of the personnel. Here was determined: age of a respondent, gender, national belonging, occupied position, religious belonging, education, etc.

For processing the primary data a standard packet SPSS 9.0 for Windows was used. Average mathematical calculation was done by the confidence scale and the analysis was made by the method of partial correlations. The method of correlation analysis was used for establishment of the union between the confidence and the motivation. In the process of analysis average meaning and dispersion were determined in the organization by the scale of the social capital evaluation (Table1).

Table 1. Average meaning and dispersion according to the social capital evaluation scale in the organization

\begin{tabular}{|l|l|l|}
\hline \multicolumn{1}{|c|}{ issues } & $\begin{array}{l}\text { average meaning and } \\
\text { dispersion } \\
\text { accoaccording to the scale } \\
\text { of social capitccapital } \\
\text { evaluation in the } \\
\text { organorganization }\end{array}$ & dispersion \\
\hline $\begin{array}{l}\text { 1. Power and control are in the hands of } \\
\text { only several persons or a group; at all } \\
\text { the levels people have power and } \\
\text { control }\end{array}$ & 2,64 & 1,20 \\
\hline $\begin{array}{l}\text { 2. Contradictions between different } \\
\text { groups are a usual case; different groups } \\
\text { positively cooperate with one another }\end{array}$ & 3,60 & 1,35 \\
\hline
\end{tabular}




\begin{tabular}{|c|c|c|}
\hline $\begin{array}{l}\text { 3. Employees cannot freely express their } \\
\text { opinions; employees freely express their } \\
\text { opinions }\end{array}$ & 2,86 & 1,34 \\
\hline $\begin{array}{l}\text { 4. Much control and restriction are as to } \\
\text { what can be done; employees are given } \\
\text { freedom of activities to conduct work. }\end{array}$ & 3,01 & 1,20 \\
\hline $\begin{array}{l}\text { 5. People have no confidence to one } \\
\text { another; people have important confidence } \\
\text { to one another }\end{array}$ & 3,39 & 0,61 \\
\hline $\begin{array}{l}\text { 6. Employees concentrate on internal } \\
\text { problems of the organization; employees } \\
\text { concentrate on the competitors }\end{array}$ & 3,05 & 1,25 \\
\hline $\begin{array}{l}\text { 7. Employees want to determine higher } \\
\text { goals; employees do not try to set wider } \\
\text { goals }\end{array}$ & 3,17 & 1,21 \\
\hline $\begin{array}{l}\text { 8. No agreement is reached on the goals } \\
\text { and criteria of the company activities; full } \\
\text { agreement is reached on the goals and } \\
\text { criteria of the company activities }\end{array}$ & 3,51 & 1,44 \\
\hline $\begin{array}{l}\text { 9. Employees often do not reach results; } \\
\text { employees almost always reach the } \\
\text { planned results }\end{array}$ & 3,25 & 0,91 \\
\hline $\begin{array}{l}\text { 10. Weak connection exists between } \\
\text { work, payment and recognition; strong } \\
\text { connection is between them }\end{array}$ & 2,97 & 1,69 \\
\hline
\end{tabular}


By the scale of the social capital evaluation an average meaning equals 3,15

By the primary results we have obtained, it is impossible to reveal existence or inexistence of confidence in the entire organization. That's why, with the purpose of deeper research average meaning and dispersion are determined by the scale of work motives evaluation. (Table 2).

Table 2 Average meaning and dispersion according to the work motives evaluation scale

\begin{tabular}{|c|c|c|}
\hline issues & $\begin{array}{l}\text { average meaning by the } \\
\text { work motives evaluation } \\
\text { scale }\end{array}$ & \\
\hline 1. Satisfaction from work & 4,11 & 8,62 \\
\hline 2. Amount of salary & 3,54 & 5,22 \\
\hline 3. Possibility for selfrealization & 4,81 & 6,31 \\
\hline 4. Positive atmosphere & 3,83 & 5,91 \\
\hline 5. Improvement of qualification & 5,61 & 6,15 \\
\hline 6. Career development & 5,42 & 8,65 \\
\hline $\begin{array}{l}\text { 7. Awareness of the company image and } \\
\text { designation }\end{array}$ & 6,55 & 7,40 \\
\hline 8. Location of work place & 7,10 & 5,71 \\
\hline 9. Possibility to use preferences & 6,98 & 7,28 \\
\hline 10. Regime of work & 6,77 & 6,53 \\
\hline
\end{tabular}


Average meaning and dispersion according to the work motives scale equals 3,01

To deepen the research we have established average meaning and dispersion according to the scale of main labor stimuli evaluation (Table 3)

Table 3 Average meaning and dispersion according to the scale of main labor stimuli evaluation

\begin{tabular}{|c|c|c|}
\hline issues & $\begin{array}{l}\text { average meaning by the scale of } \\
\text { labor stimuli }\end{array}$ & dispersion \\
\hline $\begin{array}{c}\text { 1. Participation in the } \\
\text { organization profit }\end{array}$ & 3,01 & 1,80 \\
\hline $\begin{array}{l}\text { 2. High salary } \\
\text { 4. Possibility to receive } \\
\text { premium }\end{array}$ & 3,71 & 0,63 \\
\hline $\begin{array}{c}\mathbf{5} \text { Perspective to be one } \\
\text { the owners of the } \\
\text { company }\end{array}$ & 2,41 & 1,39 \\
\hline $\begin{array}{c}\mathbf{6} \text { Settlement of } \\
\text { interesting tasks }\end{array}$ & 3,78 & 2,18 \\
\hline
\end{tabular}

average meaning and dispersion according to the work stimuli scale equals 3,48

After a short review of the situation of confidence was conducted in the company and we received average meanings according to the each respondent, on the basis of a correlative analysis we determined the relation between the factors. The methodology for organizational confidence evaliation was specified by -Cronbach's coefficient.

Table 5 Check of confidence evaluation scale by a-Cronbach's coefficient 


\begin{tabular}{|l|l|}
\hline confidence evaluation scale & $\boldsymbol{\alpha}$-Cronbach's coefficient \\
\hline 1. Power & 801 \\
\hline 2. Cooperation & 695 \\
\hline 3. Possibility to express ideas & 701 \\
\hline 4. Freedom & 717 \\
\hline 5. Confidence & 809 \\
\hline 6. Foreign orientation & 821 \\
\hline 7. Goals & 801 \\
\hline 8. Adoption of ideology & 778 \\
\hline 9. Success & 789 \\
\hline 10. Payment for work & 802 \\
\hline
\end{tabular}

Analysis of agreement $(n=47)$ showed that it is high and - Cronbach's coefficient $=$ 0,87 , which points to validity of the methodology we have used.

By the confidence evaluation scale the partial correlations of polar evidences, motives and motivation stimuli, according to gender and age, are presented in Table 6.

Table 6

\begin{tabular}{|l|l|l|l|l|l|l|l|l|l|l|l|l|}
\hline & & $\mathrm{i} 10$ & $\mathrm{i} 9$ & $\mathrm{i} 8$ & $\mathrm{i} 5$ & $\mathrm{i} 4$ & $\mathrm{i} 2$ & $\mathrm{i} 1$ & $\mathrm{~m} 1$ & $\mathrm{~m} 3$ & $\mathrm{~m} 4$ & $\mathrm{~m} 5$ \\
\hline soc1 & coeff. & - & - & 0,058 & 0,304 & - & 0,086 & 0,025 & 0,089 & 0,313 & $\begin{array}{l}- \\
0,020\end{array}$ & $\begin{array}{l}0,3 \\
00\end{array}$ \\
\hline & 0,093 & 0,252 & & & 0,164 & & & & & 0,02 & \\
\hline
\end{tabular}




\begin{tabular}{|c|c|c|c|c|c|c|c|c|c|c|c|c|}
\hline soc3 & $\begin{array}{l}\text { coeff. } \\
\text { k }\end{array}$ & 0,387 & $\begin{array}{l}- \\
0,220\end{array}$ & 0,316 & 0,224 & 0,096 & 0,249 & 0,211 & 0,343 & 0,296 & 0,150 & $\begin{array}{l}0,3 \\
29\end{array}$ \\
\hline & value & 0,009 & 0,147 & 0,035 & 0,140 & 0,533 & 0,099 & 0,165 & 0,021 & 0,048 & 0,325 & $\begin{array}{l}0,0 \\
27\end{array}$ \\
\hline \multirow[t]{2}{*}{ soc4 } & $\begin{array}{l}\text { coeff. } \\
\mathrm{k}\end{array}$ & $\begin{array}{l}- \\
0,189\end{array}$ & $\begin{array}{l}- \\
0,133\end{array}$ & 0,305 & $\begin{array}{l}- \\
0,059\end{array}$ & 0,109 & 0,189 & 0,181 & 0,157 & 0,118 & $\begin{array}{l}- \\
0,202\end{array}$ & $\begin{array}{l}0,1 \\
29\end{array}$ \\
\hline & value & 0,214 & 0,383 & 0,041 & 0,702 & 0,475 & 0,215 & 0,234 & 0,303 & 0,441 & 0,183 & $\begin{array}{l}0,3 \\
99\end{array}$ \\
\hline \multirow[t]{2}{*}{ soc6 } & $\begin{array}{l}\text { coeff. } \\
\mathrm{k}\end{array}$ & $\begin{array}{l}- \\
0,320\end{array}$ & $\begin{array}{l}- \\
0,246\end{array}$ & $\begin{array}{l}- \\
0,276\end{array}$ & 0,086 & 0,260 & 0,182 & 0,166 & 0,362 & 0,218 & 0,348 & $\begin{array}{l}0,1 \\
45\end{array}$ \\
\hline & value & 0,032 & 0,103 & 0,066 & 0,574 & 0,085 & 0,232 & 0,275 & 0,015 & 0,150 & 0,019 & $\begin{array}{l}0,3 \\
42\end{array}$ \\
\hline \multirow[t]{2}{*}{ soc7 } & $\begin{array}{l}\text { coeff. } \\
\mathrm{k}\end{array}$ & 0,292 & $\begin{array}{l}- \\
0,014\end{array}$ & $\begin{array}{l}- \\
0,177\end{array}$ & 0,116 & 0,166 & 0,190 & 0,033 & 0,239 & 0,069 & 0,291 & $\begin{array}{l}0,1 \\
47\end{array}$ \\
\hline & value & 0,052 & 0,925 & 0,244 & 0,449 & 0,276 & 0,212 & 0,828 & 0,113 & 0,653 & 0,053 & $\begin{array}{l}0,3 \\
34\end{array}$ \\
\hline \multirow[t]{2}{*}{ soc8 } & $\begin{array}{l}\text { coeff. } \\
k\end{array}$ & 0,349 & $\begin{array}{l}- \\
0,261\end{array}$ & $\begin{array}{l}- \\
0,157\end{array}$ & $\begin{array}{l}- \\
0,100\end{array}$ & 0,114 & 0,285 & 0,429 & 0,056 & 0,023 & $\begin{array}{l}- \\
0,073\end{array}$ & $\begin{array}{l}- \\
0,0 \\
01\end{array}$ \\
\hline & value & 0,019 & 0,084 & 0,304 & 0,512 & 0,455 & 0,058 & 0,003 & 0,713 & 0,880 & 0,634 & $\begin{array}{l}0,9 \\
94\end{array}$ \\
\hline \multirow[t]{2}{*}{ soc9 } & $\begin{array}{l}\text { coeff. } \\
\mathrm{k}\end{array}$ & $\begin{array}{l}- \\
0,108\end{array}$ & $\begin{array}{l}- \\
0,250\end{array}$ & $\begin{array}{l}- \\
0,017\end{array}$ & 0,039 & 0,130 & 0,005 & 0,105 & 0,184 & $\begin{array}{l}- \\
0,041\end{array}$ & $\begin{array}{l}- \\
0,040\end{array}$ & $\begin{array}{l}- \\
0,1 \\
02\end{array}$ \\
\hline & value & 0,481 & 0,098 & 0,913 & 0,797 & 0,396 & 0,972 & 0,492 & 0,228 & 0,790 & 0,794 & $\begin{array}{l}0,5 \\
05\end{array}$ \\
\hline
\end{tabular}




\begin{tabular}{|c|c|c|c|c|c|c|c|c|c|c|c|c|}
\hline soc10 & $\begin{array}{l}\text { coeff. } \\
k\end{array}$ & 0,012 & $\begin{array}{l}- \\
0,201\end{array}$ & $\begin{array}{l}- \\
0,030\end{array}$ & $\begin{array}{l}- \\
0,097\end{array}$ & $\begin{array}{l}- \\
0,103\end{array}$ & 0,081 & 0,000 & 0,316 & $\begin{array}{l}- \\
0,161\end{array}$ & 0,180 & \begin{tabular}{|l}
- \\
0,1 \\
24
\end{tabular} \\
\hline & value & 0,939 & 0,186 & 0,847 & 0,528 & 0,502 & 0,597 & 0,999 & 0,035 & 0,290 & 0,236 & \begin{tabular}{|l}
0,4 \\
18
\end{tabular} \\
\hline
\end{tabular}

\section{Analysis and Results}

It is seen from Table 1 that by the social capital evalution scale an average meaning is higher than 0,05, and no important relation was noticed between an average index of confidence per each respondent and motivation. But if we assess the motivation correlation table with separate aspects of confidence, then we can establish some important correlations. Namely, in the company "Wendy's" exists positive correlation beeween freedom of activity and possibility of selfrealization; payment for work is connected with such stimulus, as participation in the company profit; close relations exist between power and career; the scale of expression of ideas is positively related with satisfaction received from work, possibility of selfrealization and settlement of interesting tasks; orientation on competition is positively related with participation in the organization profit and the perspective to become one of the owners of the company, and negatively - with satisfaction received from work; payment for work is connected with such a stimulus, as participation in the company profit.

Thus, proceeding from the obtained results, we can make the conclusion that main hypothesis of our research, according to which was proved that the level of interpersonal and organizational confidence positively influences the motivation of employees.

\section{Conclusion}

In result of the research, existence of positive correlation between the social capital and motivation was established. That mutual relation is revealed, which exists between the social capital and the motivation.

Establishment of the mutual relation of these components is of practical value, because study and analysis of the confidence parameters for formation of an employee's motivation is an important task from the viewpoint of increase of the company competitiveness. Therefore, to increase an employee's motivation to the work activity, it is necessary to influence these parameters, which determine the company success, the possibility of which is given by the methodology we have elaborated. 


\section{References:}

Bourdieu P. (2002) Forms of capital. Economic sociology. Vol. 3. №5, November. P. 82.

Demkin O. (2004) Social capital: theoretical research foundation and operational parameters. Sociology: theory, methods, marketing. № 4. P. 67.

Malevich A. (2006) Social capital and economic interaction. Krakov, U-Press. P. 128.

Coleman J. (2001) Capital social and human / Social sciences and contemporaneity. № 3. P. 49.

Lanzmann A. (2007) Essence of social capital of the organization // New in economy and management. Issue 11. - Krakov, KSU. P. 87.

Lebedeva N., Tatarko A. (2007) Values of culture and society development. M.: SU-HSE Publishers. P. 241.

Minkute-Henriksen P., Imanavichene Zh. (2006) Social capital of the organization: methodology of research. Socis № 3. P. 98.

Nort V. (2005) Economic sociology. London. 448 p.

Fukuyama F. (2006) Confidence. Katowice, I-press.

Hekhauzen. (2011) Motivation and activity. Vol. I. 234 p.

Shaw P. (2014) Keys to confidence in the organization. M. "Delo" Publishers. P 98.

Shengelia T. (2012) Modernization and the society. Tbilisi, Universal. P. 236. 